\title{
Exchange Rates and Dominant Macro Fundamental
}

\author{
Vahid Gholampour ${ }^{1}$ \\ ${ }^{1}$ Economics Department, Bucknell University, Pennsylvania, United States \\ Correspondence: Vahid Gholampour, Academic West Building, Bucknell University, Lewisburg, Pennsylvania, \\ 17837, United States. Tel: 1-570-577-1475.
}

Received: December 16, 2020

Accepted: February 5, 2021

Online Published: June 10, 2021

doi:10.5430/ijfr.v12n4p250

URL: https://doi.org/10.5430/ijfr.v12n4p250

\begin{abstract}
Various exchange rates are driven by different macro variables. This paper uses a measure of exchange rate informativeness about future macro fundamentals to identify the dominant macroeconomic fundamental of 120 currencies. Exchange rate informativeness is defined as the share of future fundamental shocks in the variance of exchange rate changes. The distribution of exchange rate informativeness shows that the median exchange rate informativeness about the dominant macro fundamental is 0.11. Moreover, the exchange rate of most high-inflation countries is driven by expectations of the price differential. Expectations of the relative output drive the currency of countries with high export concentration.
\end{abstract}

Keywords: exchange rates, macro fundamentals

\section{Introduction}

Macro models generally assume that movements in the exchange rate are related to changes in a particular macro variable or sometimes more than one macro variable. This paper considers the possibility of heterogeneity in the relation between different exchange rates and macro variables. For instance, relative inflation might be the primary driver of the Euro-Dollar exchange rate, while the relative interest rate is the main macro variable that leads to changes in the Yen-Dollar exchange rate. In other words, the "dominant" macro variable could be different across exchange rates. This paper uses a measure of exchange rate informativeness to identify the dominant macro fundamental of 120 exchange rates and measures the contribution of future fundamental shocks to the variance of exchange rates.

For each country, the dominant fundamental is defined as the macro variable for which the exchange rate provides the most information. The idea is that investors obtain information and trade based on their expectations of the macro variable that they believe is the primary driver of the exchange rate. Forex traders receive information about future macroeconomic variables and use their information to trade currencies. As a result of private information, exchange rates contain information about future macro fundamentals. I define exchange rate informativeness as the share of future fundamental shocks in the variance of exchange rate changes. The distribution of informativeness across currencies shows that the median exchange rate informativeness about the dominant macro fundamental is 0.11 .

Money supply, price, and output are macro variables related to exchange rate movements in various models (Mark \& Sul 2001), and (Rossi 2006). Some early studies, such as (Schinasi \& Swami 1989), include trade balance as a macro variable related to exchange rate. (Clark \& West 2006) is an example of studies that examine the link between the interest rate differential and the exchange rate. This paper follows the literature and considers these five variables as potential macro drivers of exchange rates. Once the dominant macro fundamental of exchange rates is identified, countries are grouped based on their dominant macro variable. The paper reports the group average of some country-level macro variables for the groups. Comparing macro variables across the groups sheds light on the link between macro variables and the dominant fundamental for various exchange rates.

The results show that the level and volatility of inflation in the money supply and interest rate groups are below the average inflation across all countries. This is consistent with the findings of (Kollmann 2001) that predict a more significant effect of money supply shocks on the exchange rate when prices are more stable. The expectation of future price differential drives the exchange rate of most high-inflation countries. The output group includes several countries with exports concentrated in a few industries. For instance, commodity-exporting countries such as Saudi Arabia and UAE are in the output group. Exports of countries in the output group have been consistently more 
concentrated than those of other countries over the sample period. The economic growth of countries with significant export concentration depends on the future demand for a few products. Therefore, the exchange rates of these countries are most informative about their future output differential.

\section{Empirical Methodology}

\subsection{Data}

I obtain the nominal exchange rate and consumer price index data from the IMF's International Financial Statistics database (https://data.imf.org/IFS). Real GDP, money supply, interest rate, and trade balance data are from the World Bank. Data frequency is annual. I consider post-Bretton Wood years from 1973 to 2017. Countries with less than 30 observations are excluded. Table 1 provides a brief description of the variables, data sources and number of countries in the data. Exchange rate and macro data of 16 developed countries are from Jordà -Schularick-Taylor macrohistory database. The countries are United Kingdom, Belgium, Denmark, France, Germany, Italy, Netherland, Norway, Sweden, Switzerland, Canada, Japan, Finland, Portugal, Spain, and Australia. The advantage of their database over the IFS and World Bank data is the lack of gaps in the data over the sample period. They also provide country-level money supply and exchange rate indicator data for most European countries in the monetary union since 2001. See www.macrohistory.net/database/ for a detailed documentation of the macrohistory database. U.S. dollar is the base currency with all exchange rates as national currency per U.S. dollar.

Table 1. Data sources and details

\begin{tabular}{llll}
\hline Macro Fundamental & Description & Source & Number of Countries \\
\hline Exchange Rate & National currency per U.S. Dollar & IFS & 144 \\
\hline Price & Consumer Ptice Index, all items & IFS & 108 \\
\hline Money Supply & Broad Money & World Bank & 109 \\
\hline Output & Constant local currency GDP & World Bank & 118 \\
\hline Interest Rate & Real interest rate & World Bank & 50 \\
\hline Trade Balance & Net exports of goods and services & World Bank & 72 \\
\hline
\end{tabular}

\subsection{Excahnge Rate Informativeness About Dominant Fundamental}

For a given exchange rate, I measure exchange rate informativeness for various macro variables and then label the fundamental with the highest measure of informativeness as the dominant macro fundamental. Investors obtain information from various sources about future macro variables and trade currencies to profit from their information. The information, known as private information in the literature, is incorporated in exchange rates through order flow (Evans \& Lyons 2002).

More specifically, I run the following regressions:

$$
\begin{gathered}
\Delta s_{t}=\mu+\theta \Delta f_{t}+v_{t} \\
\Delta s_{t}=\alpha+\beta_{1} \Delta f_{t}+\beta_{2} \Delta f_{t+1}+\varepsilon_{t}
\end{gathered}
$$

Where $s_{t}$ is $\log$ exchange rate and $f_{t}$ is the difference between the $\log$ of fundamental in home and foreign countries. Since exchange rate and macro fundamental are I(1), the regressions are in first-difference form. The $R^{2}$ of the first regression, denoted by $R_{f_{t}}^{2}$, is the share of contemporaneous macro fundamental in the variance of exchange rate changes. Similarly, $R_{f_{t+1}, f_{t}}^{2}$ is the $R^{2}$ of the second regression that shows the share of contemporaneous and future fundamental in the variance of exchange rate changes. The difference between $R_{f_{t+1}, f_{t}}^{2}$ and $R_{f_{t}}^{2}$ is the contribution of future fundamental shocks to the variance of exchange rate changes. I compare $R_{f_{t+1}, f_{t}}^{2}-R_{f_{t}}^{2}$ across the five macro variables and the fundamental with the largest incremental $R^{2}$ is labeled the dominant macro fundamental. The dominant fundamental could be different across exchange rates. For example, let's consider Indian Rupee to U.S. Dollar exchange rate. The left hand side of regressions (1) and (2) is the one-year change in the exchange rate. I start with money supply in the right hand side of the regressions. That is, $\Delta f_{t}$ is the 
relative change in money supply in India and the United States. The difference between the $R^{2}$ of the regressions indicates the share of private information about future money supply in the variance of the exchange rate changes. According to data, informativeness of the exchange rate about future money supply is 0.04 . Similarly, we can measure informativeness of the exchange rate about future values of other macro variables by running the regressions and using price, output, interest rate, and trade balance for $f_{t}$. The results show that the measure of exchange rate informativeness is $0.02,0.00,0.16$, and 0.01 for future price, output, interest rate, and trade balance respectively. Since the exchange rate is most informative about future relative interest rate, the dominant fundamental of Indian Rupee is the interest rate.

\section{Results}

Figure 1 shows the distribution of exchange rate informativeness across 120 countries. The median exchange rate informativeness about the dominant fundamental is 0.11. Appendix Table A1 provides the full list of countries, their dominant macro fundamental, exchange rate informativeness about the dominant fundamental, and the $R^{2}$ of regressions (1) and (2). It should be noted that the currency of some countries in the data is pegged to the U.S. Dollar or Euro. Excluding those countries from the sample has virtually no effect on the median exchange rate informativeness.

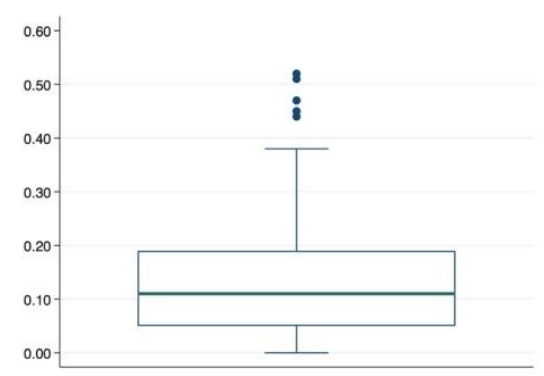

Figure 1. Distribution of exchange rate informativeness about the dominant fundamental

Table 2. Long-term macro variables and exchange rate informativeness for countries with the same dominant fundamental

\begin{tabular}{lllllll}
\hline & All & Money & Price & Output & Interest & Trade \\
\hline Number of Countries & Countries & Supply & & & Rate & Balance \\
\hline Average Inflation (\%) & 120 & 25 & 50 & 19 & 5 & 21 \\
\hline Volatility of Inflation (\%) & 12 & 7 & 19 & 7 & 5 & 8 \\
\hline Average Export/GDP (\%) & 31 & 7 & 60 & 6 & 3 & 12 \\
\hline Average Import/GDP (\%) & 36 & 35 & 34 & 40 & 28 & 43 \\
\hline Average Trade Balance/GDP $(\%)$ & 42 & 43 & 39 & 44 & 34 & 47 \\
\hline Volatility of Trade Balance/GDP $(\%)$ & -6 & -8 & -6 & -4 & -6 & -4 \\
\hline Median Exchange Rate Informativeness & 8 & 9 & 8 & 10 & 7 & 7 \\
\hline
\end{tabular}

To shed light on the link between the economic characteristics of countries and the dominant fundamental of their exchange rate, I compare long-term macro variables of countries with different dominant fundamentals. Five country groups are considered for the five macro fundamentals: money supply, price, output, interest rate, and trade balance. I assign each country in the data to one of the five groups based on the dominant fundamental of its exchange rate. All countries whose exchange rate is most informative about future money supply are placed in the "money supply" group. "price", "output", "interest rate", and "trade balance" groups are similarly populated. Long-term group 
average and volatility of country-level macro variables such as inflation, exports, imports, and trade balance are reported in Table 2.

The table shows that the level and volatility of inflation in the price group are higher than those of an average country in the data. The exchange rates of high-inflation countries are mainly driven by expectations of the future price differential, leaving it unsurprising that price differential is the dominant fundamental for the exchange rates of these countries. The level and volatility of inflation in the money supply and interest rate groups are lower than those of an average country. One possible explanation is that monetary policy has a more significant effect on the nominal exchange rate when prices are stable (Kollmann 2001). Therefore, the exchange rates of some low-inflation countries are driven by expectations of future money supply or interest rate.

It should be noted that low inflation does not automatically place a country in the money supply or interest rate group. Other factors might dominate the relationship between the nominal exchange rate and monetary policy shocks. For instance, countries in the output group have low and stable inflation, but their exchange rates are driven by expectations of the future output differential.

There are a number of commodity-exporting countries such as Saudi Arabia and Kuwait in the output group. Major oil exporting countries in the Middle East pegged their currency to the U.S. dollar during most of the sample period. The reported measures of informativeness for these countries are mainly driven by exchange rate changes during the early years of the sample period when the currencies were not pegged. The group also includes Malaysia and Philippines, where electronics and integrated circuits account for a large share of exports. The economic growth of countries whose exports are concentrated in a single industry is mainly driven by expectations of demand for the industry's products. Therefore, the exchange rates of these countries are most informative about their future output differential. To illustrate this point, I obtain the country-level export diversification index from IMF and compare the index across countries. Figure 2 shows the distribution of export diversification index for countries in the output group and other countries in the data. The figure indicates that exports of countries in the output group have been more concentrated than those of other groups over the past four decades.

Trade-related variables are not significantly different across groups. The only notable observation is above-average exports and imports to GDP in the trade balance group. This result is almost entirely driven by Singapore and Hong Kong, with ratios well above one for these two trade hubs.

\section{Conclusion}

This paper measures informativeness of 120 exchange rates about future values of relative money supply, price, output, interest rate, and trade balance. Exchange rate informativeness is defined as the share of future macro fundamental shocks in the variance of exchange rate changes. Different currencies are driven by different macro variables. The paper uses the measure of exchange rate informativeness to identify the dominant macro fundamental of exchange rates. The dominant fundamental of a currency is the macro variable for which the exchange rate provides the most information. The distribution of exchange rate informativeness about the dominant fundamental shows significant variation in informativeness across currencies, and the median informativeness is 0.11 .

In order to shed light on the link between the dominant fundamental of exchange rates and the economic characteristics of countries, the paper places all countries in the data in five groups based on their dominant fundamental and compares some long-term macro variables across the groups. The level and volatility of inflation are low in countries whose exchange rate is driven by the expectation of relative money supply or interest rate. The expectation of price differential drives the exchange rate of most high-inflation countries. Countries whose exchange rate is driven by the expectation of relative output have a higher measure of export concentration.

It should be noted that there are some limits to this study. For instance, using annual data over the sample period allows me to include many countries in the study but having only 44 observations might give rise to estimation error. In this paper, I use the realized fundamental as a proxy for average expectation about the future macro fundamental. This assumption is realistic if the average of information error across agents is zero. Future research can advance this study by including other macro variables and using fund flows or surveys as proxies for average expectations about future fundamentals. 


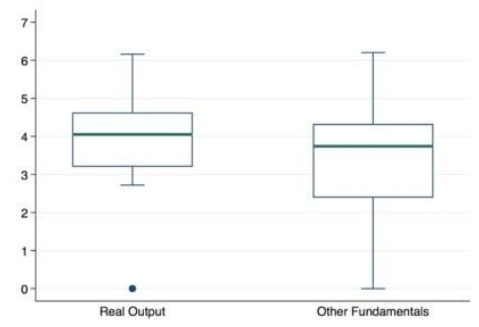

(a) 1980

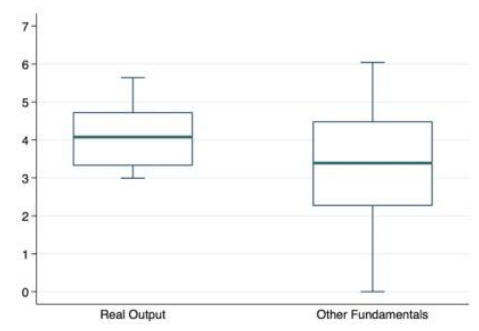

(c) 2000

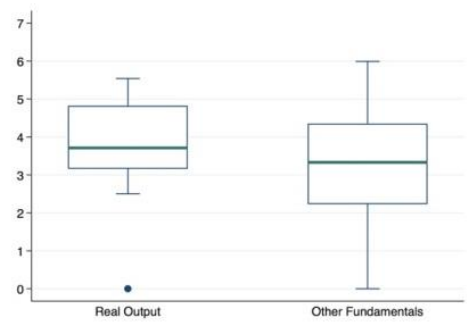

(b) 1990

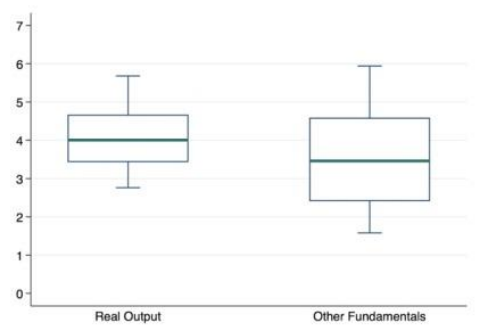

(d) 2010

Figure 2. Distribution of IMF export diversification index

Note: "Real Output" group includes countries whose exchange rate is most informative about future real output and "Other Fundamentals" group consist of other countries in the sample whose exchange rate is most informative about other macro fundamentals (money supply, price, ...). Higher values of the index are associated with more export concentration. Panels a, b, c, d show the cross-sectional distribution of the index in 1980, 1990, 2000, 2010 respectively.

\section{References}

Barbara, R. (2006). Are exchange rates really random walks? Some evidence robust to parameter instability. Macroeconomic Dynamics, 10(1), 20-38.

Clark, T. E., \& Kenneth, D. W. (2006). Using out-of-sample mean squared prediction errors to test the martingale difference hypothesis. Journal of Econometrics, $135(1-2), \quad$ 155-186. https://doi.org/10.1016/j.jeconom.2005.07.014

Evans, M. D. D., \& Richard, K. L. (2002). Order flow and exchange rate dynamics. Journal of Political Economy $110(1), 170-180$.

Mark, N. C., \& Donggyu, S. (2001). Nominal exchange rates and monetary fundamentals: evidence from a small post-Bretton Woods panel. Journal of International Economics, 53(1), 29-52. https://doi.org/10.1016/S0022-1996(00)00052-0

Òscar, J., Schularick, M., \& Alan, M. T. (2017). Macrofinancial history and the new business cycle facts. In M. Eichenbaum, \& J. A. Parker (Eds.), NBER Macroeconomics Annual 2016 (Vol. 31). Chicago: University of Chicago Press.

Robert, K. (2001). The exchange rate in a dynamic-optimizing business cycle model with nominal rigidities: a quantitative investigation. Journal of International Economics, 55(2), 243-262. https://doi.org/10.1016/S0022-1996(01)00087-3

Schinasi, G. J., \& Swamy, P. A. V. B. (1989). The out-of-sample forecasting performance of exchange rate models when coefficients are allowed to change. Journal of International Money and Finance, 8(3), 375-390. https://doi.org/10.1016/0261-5606(89)90004-1 


\section{Appendix A}

Table A1 shows the list of 120 countries and the dominant macro fundamental of their exchange rate. The dominant fundamental of an exchange rate is the macro variable for which the contribution of private information to the variance of exchange rate is the highest of the five macro variables. Relative money supply, price, output, interest rate, and trade balance are the five macro fundamentals. The table also reports exchange rate informativeness about the dominant fundamental. The last two columns show $R_{f_{t+1}, f_{t}}^{2}$ and $R_{f_{t}}^{2} \cdot R_{f_{t+1}, f_{t}}^{2}$ is found by regressing $s_{t}-s_{t-1}$ on $f_{t}-f_{t-1}$ and $f_{t+1}-f_{t}$. Similarly, $R_{f_{t}}^{2}$ is found from the regression of $s_{t}-s_{t-1}$ on $f_{t}-f_{t-1}$.

Informativeness of exchange rate, denoted by $I_{f}$, is

$$
I_{f}=R_{f_{t+1}, f_{t}}^{2}-R_{f_{t}}^{2}
$$

Table A1. Dominant fundamental of exchange rates and exchange rate informativeness about the dominant fundamental

\begin{tabular}{|c|c|c|c|c|}
\hline Country & $f$ & $I_{f}$ & $R_{f_{t+1}, f_{t}}^{2}$ & $R_{f_{t}}^{2}$ \\
\hline Algeria & Price & 0.13 & 0.39 & 0.26 \\
\hline Antigua and Barbuda & Money & 0.10 & 0.11 & 0.01 \\
\hline Argentina & Trade & 0.47 & 0.54 & 0.07 \\
\hline Australia & Money & 0.12 & 0.12 & 0.00 \\
\hline Bahrain & Price & 0.45 & 0.47 & 0.02 \\
\hline Bangladesh & Interest & 0.11 & 0.14 & 0.03 \\
\hline Barbados & Price & 0.12 & 0.30 & 0.18 \\
\hline Belgium & Price & 0.23 & 0.24 & 0.01 \\
\hline Belize & Money & 0.07 & 0.18 & 0.11 \\
\hline Benin & Trade & 0.07 & 0.09 & 0.02 \\
\hline Bhutan & Price & 0.04 & 0.26 & 0.22 \\
\hline Bolivia & Price & 0.21 & 0.33 & 0.12 \\
\hline Botswana & Output & 0.02 & 0.02 & 0.00 \\
\hline Brunei Darussalam & Price & 0.21 & 0.21 & 0.00 \\
\hline Burkina Faso & Money & 0.05 & 0.16 & 0.11 \\
\hline Burundi & Money & 0.03 & 0.04 & 0.01 \\
\hline Cabo Verde & Price & 0.00 & 0.00 & 0.00 \\
\hline Cameroon & Trade & 0.08 & 0.08 & 0.00 \\
\hline Canada & Trade & 0.07 & 0.13 & 0.06 \\
\hline Central African Rep. & Price & 0.11 & 0.24 & 0.13 \\
\hline Chad & Price & 0.12 & 0.46 & 0.34 \\
\hline Chile & Trade & 0.05 & 0.39 & 0.34 \\
\hline China & Money & 0.03 & 0.11 & 0.08 \\
\hline Comoros & Trade & 0.10 & 0.14 & 0.04 \\
\hline Congo, Rep. & Price & 0.07 & 0.07 & 0.00 \\
\hline Costa Rica & Price & 0.37 & 0.71 & 0.34 \\
\hline Cyprus & Trade & 0.16 & 0.24 & 0.08 \\
\hline
\end{tabular}




\begin{tabular}{|c|c|c|c|c|}
\hline Ivory Coast & Price & 0.00 & 0.07 & 0.07 \\
\hline Denmark & Price & 0.07 & 0.07 & 0.00 \\
\hline Dominica & Price & 0.06 & 0.53 & 0.47 \\
\hline Dominican Rep. & Money & 0.24 & 0.29 & 0.05 \\
\hline Ecuador & Price & 0.29 & 0.79 & 0.50 \\
\hline Egypt & Price & 0.21 & 0.23 & 0.02 \\
\hline El Salvador & Money & 0.04 & 0.19 & 0.15 \\
\hline Equatorial Guinea & Price & 0.05 & 0.32 & 0.27 \\
\hline Eswatini & Trade & 0.04 & 0.04 & 0.00 \\
\hline Ethiopia & Output & 0.18 & 0.22 & 0.04 \\
\hline Fiji & Money & 0.06 & 0.21 & 0.15 \\
\hline Finland & Money & 0.17 & 0.17 & 0.00 \\
\hline France & Price & 0.08 & 0.13 & 0.05 \\
\hline Gabon & Trade & 0.01 & 0.02 & 0.01 \\
\hline Gambia & Money & 0.15 & 0.15 & 0.00 \\
\hline Germany & Price & 0.19 & 0.19 & 0.00 \\
\hline Ghana & Price & 0.12 & 0.21 & 0.09 \\
\hline Greenland & Output & 0.04 & 0.06 & 0.02 \\
\hline Grenada & Money & 0.02 & 0.09 & 0.07 \\
\hline Guatemala & Trade & 0.34 & 0.34 & 0.00 \\
\hline Guinea-Bissau & Price & 0.05 & 0.06 & 0.01 \\
\hline Guyana & Interest & 0.12 & 0.39 & 0.27 \\
\hline Haiti & Price & 0.17 & 0.21 & 0.04 \\
\hline Honduras & Price & 0.28 & 0.46 & 0.18 \\
\hline Hong Kong & Trade & 0.19 & 0.20 & 0.01 \\
\hline Hungary & Money & 0.02 & 0.07 & 0.05 \\
\hline Iceland & Trade & 0.29 & 0.32 & 0.03 \\
\hline India & Interest & 0.16 & 0.17 & 0.01 \\
\hline Isle of Man & Output & 0.08 & 0.08 & 0.00 \\
\hline Israel & Price & 0.08 & 0.91 & 0.83 \\
\hline Italy & Price & 0.05 & 0.14 & 0.09 \\
\hline Jamaica & Price & 0.38 & 0.53 & 0.15 \\
\hline Japan & Interest & 0.20 & 0.21 & 0.01 \\
\hline Jordan & Price & 0.20 & 0.33 & 0.13 \\
\hline Kenya & Price & 0.12 & 0.26 & 0.14 \\
\hline Kuwait & Output & 0.04 & 0.05 & 0.01 \\
\hline Lesotho & Price & 0.09 & 0.22 & 0.13 \\
\hline Liberia & Money & 0.14 & 0.21 & 0.07 \\
\hline Libya & Price & 0.07 & 0.26 & 0.19 \\
\hline Macao & Money & 0.12 & 0.12 & 0.00 \\
\hline
\end{tabular}




\begin{tabular}{|c|c|c|c|c|}
\hline Malawi & Price & 0.37 & 0.53 & 0.16 \\
\hline Malaysia & Output & 0.31 & 0.33 & 0.02 \\
\hline Maldives & Money & 0.04 & 0.05 & 0.01 \\
\hline Mali & Output & 0.04 & 0.06 & 0.02 \\
\hline Malta & Output & 0.04 & 0.05 & 0.00 \\
\hline Mauritania & Interest & 0.05 & 0.11 & 0.06 \\
\hline Mauritius & Trade & 0.17 & 0.20 & 0.03 \\
\hline Mexico & Price & 0.51 & 0.79 & 0.28 \\
\hline Morocco & Price & 0.13 & 0.15 & 0.02 \\
\hline Mozambique & Trade & 0.03 & 0.03 & 0.00 \\
\hline Myanmar & Output & 0.01 & 0.01 & 0.00 \\
\hline Namibia & Trade & 0.03 & 0.05 & 0.02 \\
\hline Nepal & Price & 0.07 & 0.11 & 0.04 \\
\hline Netherlands & Price & 0.19 & 0.19 & 0.00 \\
\hline New Zealand & Trade & 0.29 & 0.34 & 0.05 \\
\hline Nicaragua & Trade & 0.52 & 0.56 & 0.04 \\
\hline Niger & Money & 0.05 & 0.05 & 0.00 \\
\hline Nigeria & Money & 0.07 & 0.08 & 0.01 \\
\hline Norway & Money & 0.09 & 0.10 & 0.01 \\
\hline Oman & Output & 0.05 & 0.06 & 0.01 \\
\hline Pakistan & Output & 0.03 & 0.03 & 0.00 \\
\hline Papua new guinea & Price & 0.35 & 0.42 & 0.07 \\
\hline Philippines & Output & 0.38 & 0.46 & 0.08 \\
\hline Poland & Price & 0.17 & 0.78 & 0.61 \\
\hline Portugal & Price & 0.09 & 0.26 & 0.17 \\
\hline Qatar & Price & 0.03 & 0.05 & 0.02 \\
\hline Rwanda & Price & 0.11 & 0.11 & 0.00 \\
\hline Samoa & Price & 0.08 & 0.15 & 0.07 \\
\hline Saudi Arabia & Output & 0.15 & 0.15 & 0.00 \\
\hline Senegal & Trade & 0.09 & 0.35 & 0.26 \\
\hline Seychelles & Price & 0.44 & 0.49 & 0.05 \\
\hline Singapore & Trade & 0.27 & 0.31 & 0.04 \\
\hline Solomon islands & Money & 0.07 & 0.14 & 0.07 \\
\hline South Africa & Price & 0.23 & 0.23 & 0.00 \\
\hline Spain & Price & 0.10 & 0.13 & 0.03 \\
\hline Sri Lanka & Output & 0.09 & 0.15 & 0.06 \\
\hline St. Lucia & Money & 0.15 & 0.21 & 0.06 \\
\hline St. Vincent & Output & 0.16 & 0.17 & 0.01 \\
\hline Sweden & Price & 0.09 & 0.09 & 0.00 \\
\hline Switzerland & Price & 0.11 & 0.11 & 0.00 \\
\hline
\end{tabular}




\begin{tabular}{lllll}
\hline Syria & Output & 0.24 & 0.26 & 0.02 \\
\hline Tanzania & Money & 0.09 & 0.13 & 0.04 \\
\hline Thailand & Trade & 0.26 & 0.26 & 0.00 \\
\hline Togo & Money & 0.03 & 0.09 & 0.06 \\
\hline Tonga & Output & 0.06 & 0.08 & 0.02 \\
\hline Trinidad and tobago & Output & 0.01 & 0.10 & 0.09 \\
\hline Tunisia & Trade & 0.14 & 0.14 & 0.00 \\
\hline United Arab Emirates & Output & 0.02 & 0.29 & 0.27 \\
\hline United Kingdom & Money & 0.10 & 0.12 & 0.02 \\
\hline Uruguay & Price & 0.15 & 0.40 & 0.25 \\
\hline Vanuatu & Price & 0.13 & 0.13 & 0.00 \\
\hline Venezuela & Money & 0.28 & 0.33 & 0.05 \\
\hline Zambia & Price & 0.15 & 0.54 & 0.39
\end{tabular}

\section{Copyrights}

Copyright for this article is retained by the author(s), with first publication rights granted to the journal.

This is an open-access article distributed under the terms and conditions of the Creative Commons Attribution license (http://creativecommons.org/licenses/by/4.0/). 